
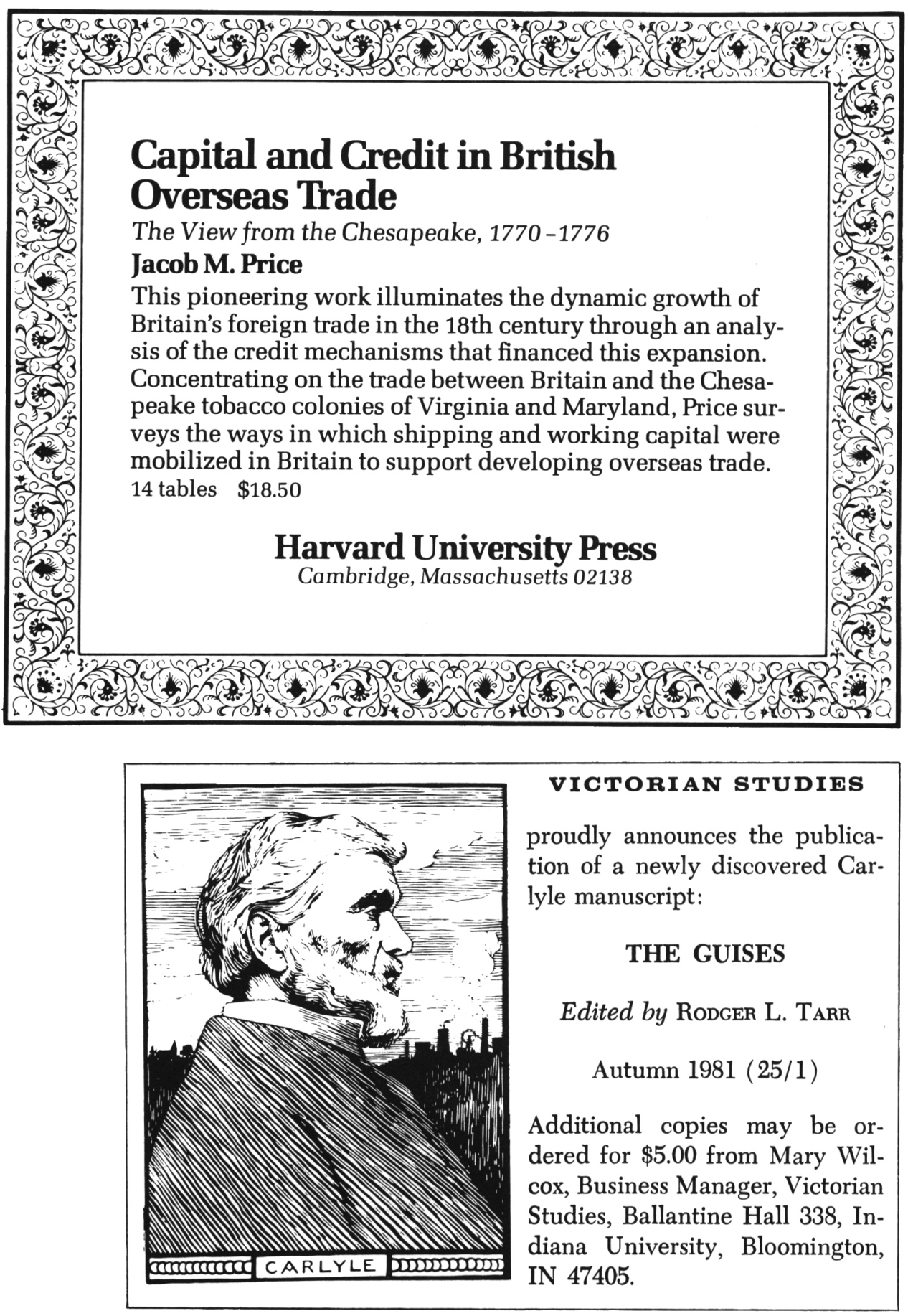


\title{
THE EIGHTEENTH CENTURY
}

\section{Theory and Tnterpretation}

\author{
Published Winter, Spring, and Autumn \\ by Texas Tech Press
}

Editors

Jeffrey $R$. Smitten

Joel C. Weinsheimer

Editorial Board

A. Owen Aldridge

Paul K. Alkon

Michael Fried

Alexander Gelley

Josué Harari

J. Jean Hecht

C. P. Ives

Isaac Kramnick

Lawrence I. Lipking

Christie V. McDonald

Earl Miner

Walter Moser

Mark Poster

Ralph W. Rader

Ronald C. Rosbottom

G. S. Rousseau

Rémy G. Saisselin

Hayden White
Selected Contents of Volume 21 (1980)

Leopold Damrosch on Johnson's Criticism Robert Adams Day on Epistolary Fiction Alexander Gelley on Character Richard Harp on Goldsmith Biography Dayton Haskin on Richard Baxter George Armstrong Kelly on the New Hero C. R. Kropf on Organic Unity Christie McDonald on the Encyclopeddie Donald Marshall on Richard Hurd Michael Murray on Heidegger and Hölderlin Jayme Sokolow on Count Rumford

Subscriptions are $\$ 9.00$ (individuals) and $\$ 12.00$ (institutions) per year, plus $\$ 2.00$ for mailing outside North America. Address subscriptions to:

Texas Tech Press

Sales Office

Texas Tech University Library

Lubbock, Texas 79409

Other correspondence should be addressed to:

The Editors

The Eighteenth Century:

Theory and Interpretation

P.O. Box 4530

Texas Tech University

Lubbock, Texas 79409 


\section{THE CAMBRIDGE CONNECTION AND} THE ELIZABETHAN SETTLEMENT OF 1559

\section{WINTHROP S. HUDSON}

"A distinguished work of scholarship which makes an original and valuable contribution to Tudor and Elizabethan history. Hudson has brought to light facts of real significance. He presents a convincing alternative picture to the one offered by Sir John Neale." Perez Zagorin

\section{THE ECONOMIST IN PARLIAMENT, $1780-1868$ \\ FRANK WHITSON FETTER}

"A valuable contribution to scholarship, which will have great and lasting usefulness." A. W. Coats. "A major contribution to the history of British economics. The work is based so much on original sources and quotes so extensively that it approaches being a primary source itself." William D. Grampp

$\$ 18.75$

\section{CLIO UNBOUND}

Perception of the Social and Cultural Past in Renaissance England

ARTHUR B. FERGUSON

"Ferguson has deepened and broadened our view of the history of history . . . A study that is as valuable as it is magisterial. In his own way Ferguson has contributed further to the unbinding of Clio." American Historical Review

$\$ 22.75$

\section{THE COLLECTED LETTERS OF THOMAS AND JANE WELSH CARLYLE}

Volumes 8 and 9 (1835-1837), Duke-Edinburgh Edition CHARLES RICHARD SANDERS Duke University, General Editor

KENNETH J. FIELDING

University of Edinburgh, Co-Editor

To be published Fall/Winter 1980

$\$ 25.00$ per volume $\$ 48.75$ the two-volume set

Publisher pays postage on prepaid orders.

\section{DUKE UNIVERSITY PRESS}

6697 Collge Station / Durham, North Carolina 27708 


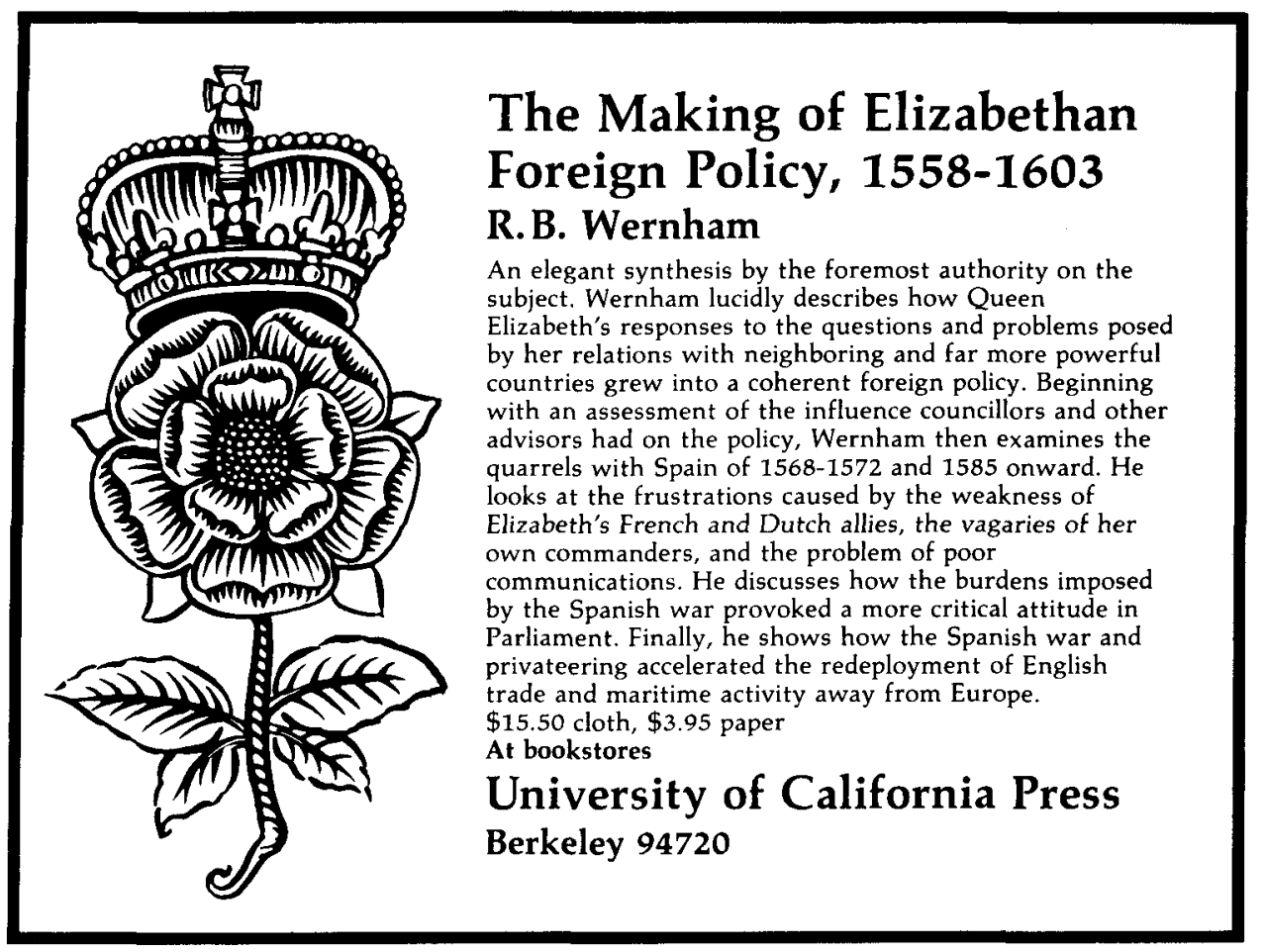


